IGOR KĄKOLEWSKI

Centrum Badań Historycznych PAN w Berlinie Instytut Nauk Politycznych, Uniwersytet

Warmińsko-Mazurski w Olsztynie

\title{
SPECYFIKA PROCESÓW CHRYSTIANIZACYJNYCH W HISTORII POLSKI W KONTEKSTACH HISTORII POWSZECHNEJ
}

Na początek kilka refleksji ogólnych. Po pierwsze, gdy zastanawiałem się nad szeregiem doniosłych problemów poruszonych w ankiecie „Kwartalnika Historycznego", nasunęło mi się pytanie zasadnicze: czy Redakcji chodziło o chrystianizację i dechrystianizację jako zjawiska charakterystyczne dla początku dziejów Polski oraz tzw. epoki nowoczesności (od przełomu XVIII/XIX w. do współczesności), czy o procesy chrystianizacji składające się na wielowątkowy proces cywilizacyjny obejmujący ewolucję form życia religijnego, kulturalnego i społecznego w długim trwaniu i wykraczający poza rozdziały „prologu” i „epilogu” dziejów narodowych? Tak pojęte procesy chrystianizacyjne mają dłuższy zasięg niż wczesnośredniowieczna chrystianizacja rozumiana jako proces przyjęcia, upowszechniania i internalizacji podstawowych treści i wartości chrześcijańskich. Chrystianizacja przebiegająca w okresie wczesnopiastowskim byłaby zatem zaledwie wstępem do bardziej kompleksowych, trwających nie tylko przez następne stulecia, lecz także epoki kulturowych przemian chrześcijaństwa. Przyzwyczajony do konwencjonalnych cezur dziejów powszechnych i Polski, patrząc przede wszystkim z perspektywy własnej specjalizacji, starałem się wziąć pod uwagę fakt, że chrześcijaństwo - tak samo zresztą jak inne wielkie religie światowe w różnych epokach konfrontowało się z podobnymi pytaniami i problemami, które jednak z racji różnego kontekstu dziejowego mogły prowadzić do odmiennych odpowiedzi i rozwiązań.

Po drugie, refleksja na pozór banalna z punktu widzenia tzw. historii pierwszego stopnia (zdarzeniowej), ważniejsza zaś z perspektywy obecnie modnej historii drugiego stopnia (badań nad kulturą pamię- 
ci): Wprowadzenie chrześcijaństwa w części państw słowiańskiej Europy Środkowo-Wschodniej wiąże się ściśle z mitami fundacyjnymi państwowości, które przetrwały po dzień dzisiejszy. Pod tym względem historia tzw. młodszej Europy może się wydawać - choć to złudzenie wynikające z meandrów i specyfiki badań nad kulturami pamięci - dłuższa niż państw „starej” Europy Zachodniej. Tak np. mierzona historia Polski jako państwa byłaby „dłuższa” niż historia państwowości Anglii, Włoch czy Niemiec, biorąc pod uwagę w tym ostatnim przypadku nie tylko skomplikowane tradycje i strukturę Świętego Cesarstwa Rzymskiego, lecz także typowe dla niemieckiej kultury pamięci poczucie kontynuacji w dziejach Niemiec - tak regionalnych, jak i ogólnopaństwowych. W przypadku bardziej homogenicznej polskiej kultury pamięci, szczególnie po II wojnie światowej, kwestia milenijnej kontynuacji państwa polskiego - pomimo dyskontynuacji zaborów i okupacji - umacnianej oficjalną polityką historyczną, czego przykładem były hucznie obchodzone w Polskiej Rzeczypospolitej Ludowej w 1966 r. konkurencyjnie obchody: kościelne Milenium Chrztu Polski oraz partyjno-państwowe Tysiąclecia Państwa Polskiego, w powszechnej świadomości Polaków zdaje się nie budzić wątpliwości. Przy tym po zmianach granic w 1945 r. i homogenizacji składu etnicznego ludności zatarciu w zbiorowej pamięci uległ drugi - obok piastowskiego - mit fundacyjny: jagielloński, ściśle związany z chrystianizacją Litwy i chętnie wcześniej w polskiej kulturze pamięci podkreślaną „misyjną" rolą w tym procesie Polski.

Spróbujmy zatem z perspektywy długiego trwania, biorąc jako pretekst dwa wspomniane mity fundacyjne, spojrzeć na procesy chrystianizacyjne w historii Polski w szerszym kontekście europejskim. Patrząc $z$ tego punktu widzenia, można powiedzieć, że państwo polskie podczas ostatniego tysiąclecia przechodziło przynajmniej dwie fazy szeroko pojętych procesów chrystianizacyjnych. Faza pierwsza wiąże się ściśle z piastowskim mitem fundacyjnym i przyjęciem chrztu w obrządku łacińskim przez Mieszka I w 966 r. Skąpa baza źródłowa umożliwia nam jedynie hipotetyczną rekonstrukcję pierwszych etapów chrystianizacji społeczeństwa w okresie wczesnopiastowskim. Między innymi późnośredniowieczne źródła z Litwy właściwej oraz państwa zakonnego w Prusach terenów do XIII/XIV w. nieschrystianizowanych - potwierdzają, że upowszechnianie chrześcijaństwa musiało być procesem długotrwałym, wywołującym fale tzw. reakcji pogańskiej oraz sprzyjającym nakładaniu się na dawne obyczaje pogańskie nowych form pobożności chrześcijańskiej. W konsekwencji mogło to prowadzić do powstania form synkretycznych, tylko formalnie chrześcijańskich, a wyeliminowanie $\mathrm{z}$ nich substratu dawnych wierzeń wymagało dłuższego czasu. 
Przy tym chrystianizacja Polski od połowy X w. przybiegała w podobnym kontekście jak w innych państwach młodszej Europy, tj. tych obszarach środkowo-wschodnioeuropejskich, które we wcześniejszej epoce nie znalazły się pod wpływem cywilizacyjnym Imperium Rzymskiego, w średniowieczu zaś pozostawały areną oddziaływania dwóch obrządków: łacińskiego i bizantyńsko-słowiańskiego. W pierwszej fazie rozwoju kultury chrześcijańskiej, trwającej do połowy XIV w., dla ziem polskich charakterystyczna była wyłączna dominacja chrześcijaństwa w obrządku łacińskim, stopniowo stabilizującego swe wpływy wśród stosunkowo jednorodnej etnicznie rdzennej populacji.

Początek drugiej fazy można datować od połowy XIV w. i hasłowo nazwać chrystianizacją w sytuacji wielokulturowości. Związana ona była ściśle ze zmianą granic Królestwa Polskiego i ich - w dosłownym słowa znaczeniu - reorientancją najpierw wskutek przyłączenia Rusi Czerwonej przez Kazimierza Wielkiego, niedługo potem zaś unii polsko-litewskich. Wieloetniczność i wielokonfesyjność staną się od tego momentu elementami skomplikowanych procesów kulturotwórczych, w tym chrystianizacyjnych. Procesy te pogłębi rozwój reformacji w XVI w., a dokładniej dwie reformy chrześcijaństwa - ewangelicka i katolicka - redefiniujące chrześcijaństwo we wczesnonowożytnej Europie łacińskiej. Zarazem w okresie od schyłku XIV do początków XVII w. miała miejsce chrystianizacja (w ścisłym znaczeniu) w obrządku łacińskim terenów Litwy właściwej oraz hamowana postępami protestantyzmu i defensywną postawą Cerkwi prawosławnej - ekspansja katolicyzmu (unia brzeska). Oba zjawiska odcisnęły długotrwały znak na obliczu chrześcijaństwa w wielonarodowej Rzeczypospolitej.

W wyniku zmian zachodzących od końca XIV w. w państwie polsko-litewskim pojawiły się nowe, na wcześniejszych etapach chrystianizacji Polski w niewielkim tylko stopniu istotne problemy: stosunku wyznań chrześcijańskich do siebie, a także do zamieszkujących terytorium wieloetnicznej Korony i Litwy sąsiadów wyznających religie niechrześcijańskie - judaizmu i islamu. Kształtująca się od przełomu średniowiecza i wczesnej nowożytności nowa kompozycja wyznaniowo-etniczna populacji dawnej Rzeczypospolitej w drugiej połowie XVI i początkach XVII w. obejmowała zaledwie 40-50\% ludności, którą można określić (nieco ahistorycznie) jako etnicznie polską, przeważnie wyznania rzymskokatolickiego, choć ze znaczącym politycznie odsetkiem ewangelików. Spośród wielu innych grup najliczniejsi byli Rusini (około $30 \%$ populacji), początkowo głównie wierni Cerkwi prawosławnej, wkrótce zaś również unickiej, a także dynamicznie wzrastająca populacja Żydów, którzy w połowie XVIII w. będą stanowili około 7\% społeczeństwa Rzeczypospolitej. 
Procesy chrystianizacyjne w sytuacji wielokulturowości wymagały wypracowania pewnych mechanizmów neutralizacji potencjalnych i rzeczywistych konfliktów. W tym miejscu dotykamy kwestii tolerancji i rozpowszechnionej wizji dawnej Rzeczypospolitej jako „państwa bez stosów” w okresie wstrząsanej wojnami religijnymi zachodniej części Europy. Wizja ta - spopularyzowana tytułem książki Janusza Tazbira ${ }^{1}$, czytanej jednak często bez dogłębnej zrozumienia treści dzieła tego wybitnego historyka ciągle dominuje w syntetyzujących i popularnych ujęciach przedstawiających Rzeczpospolitą Obojga Narodów jako unikalną arkadię - kolebkę aktu konfederacji warszawskiej z 1573 r. wyprzedzającego swą oryginalnością dokumenty innych współczesnych pokojów religijnych. Tymczasem panorama stosunków wyznaniowych wczesnonowożytnej Europy Środkowo-Wschodniej ukazuje podobny do polsko-litewskiego poziom i typ tolerancji w Siedmiogrodzie w połowie XVI czy od początku XVII w. w habsburskim Królestwie Węgier, nie wspominając już o osmańskiej Turcji, którą również należałoby uznać za przysłowiowe „państwo bez stosów”, cywilizację islamu zaś - zaliczającą muzułmanów, Żydów i chrześcijan do „ludów Księgi" - za bardziej tolerancyjną od cywilizacji chrześcijańskiej, przynajmniej w epoce wojen religijnych. Wydaje się, że jedną z najważniejszych przyczyn, dla których obszary, o których mowa, osiągnęły stosunkowo wysoki poziom tolerancji religijnej, był charakterystyczny dla nich fenomen i tradycje wielokulturowości, o typie niespotykanym w ówczesnej Europie Zachodniej. W konkretnych sytuacjach mogła ona co prawda prowadzić do napięć i konfliktów, jednak wielowiekowa tradycja wielokulturowości sprzyjała raczej układaniu w sposób pokojowy warunków współżycia rozmaitych grup etnicznych i religijnych - tak chrześcijańskich, jak i niechrześcijańskich.

Oprócz tego w dawnej Rzeczypospolitej istotną rolę odgrywał fakt, że w sytuacji państwa i społeczeństwa stanowego niektóre grupy etniczno-religijne, jak np. Żydzi i Ormianie, osiągnęły pozycję podobną do stanów społecznych, z gwarantowanymi im tradycyjnymi przywilejami i swobodami. Rzecz jasna trzeba też pamiętać, że tolerancja we wczesnej epoce nowożytnej miała charakter zdecydowanie pragmatyczny - łac. tolerare znaczyło „ścierpieć” (tj. znosić różniących się w wierze aż do momentu ich nawrócenia na uznawaną za jedynie słuszną religię lub wyznanie). Takie rozumienie tolerancji przypominało jej koncepcję postulowaną we wcześniejszych epokach przez niektóre autorytety świata chrześcijańskiego wobec wyznawców religii niechrześcijańskich. Św. Tomasz z Akwinu twier-

${ }^{1}$ J. Tazbir, Państwo bez stosów. Szkice z dziejów tolerancji w Polsce XVI i XVII w., Warszawa 1967. 
dził, iż w istocie nie jest rzeczą dobrą,jeśli istnieją kulty oparte na błędnych wierzeniach, te ostatnie można jednak tolerować dla uniknięcia większego zła bądź dla uzyskania większej korzyści. Podobny sposób myślenia na wielokulturowym gruncie polskim u schyłku średniowiecza nie był obcy też Pawłowi Włodkowicowi, a w epoce odrodzenia i reformacji irenistycznie nastawionym intelektualistom.

W Europie łacińskiej, w tym Rzeczypospolitej, do pogłębienia oddziaływania chrześcijaństwa przyczyniły się zjawiska kulturowe wywołane przez reformację: wprowadzenie języków narodowych do liturgii ewangelickiej oraz poszerzenie możliwości katechizacji w tychże językach również w wyznaniach nieprotestanckich dzięki wielkiej rewolucji medialnej XVI w. - upowszechnieniu druku. Potwierdza to eksplozja wydawnicza zarówno tłumaczeń na słowiańskie języki narodowe protestanckich Biblii, jak i bogatej literatury religijnej we wszystkich głównych nurtach konfesyjnych chrześcijaństwa w Rzeczypospolitej. Kwestia wprowadzenia języka narodowego do liturgii oraz jako kluczowego instrumentu katechizacji w Europie Środkowo-Wschodniej pojawiła się jednak już o wiele wcześniej - w trakcie wczesnośredniowiecznej chrystianizacji, w IX w. podczas akcji chrystianizacyjnej św. św. Cyryla i Metodego i w konsekwencji doprowadzić miała do wykształcenia się rytu bizantyńsko-słowiańskiego. Początkowo również stanowisko Kościoła łacińskiego w tej kwestii było podzielone, jak świadczą o tym słowa papieża Jana VIII z 880 r.: „Nie sprzeciwia się też nic prawdziwej wierze i nauce, by w języku słowiańskim sprawować mszę świętą, czytać świętą Ewangelię oraz lekcje ze Starego i Nowego Testamentu [- - ]. Ten bowiem, który stworzył trzy główne języki: hebrajski, grecki i łaciński, stworzył też i wszystkie inne na swoją większą chwałę"2.

W okresie reformacji powróciły postulaty stawiane w Europie Środkowo-Wschodniej podczas akcji misyjnych we wczesnym średniowieczu o język narodowy w liturgii oraz tłumaczenie nań Biblii jako kluczowych instrumentów upowszechniania prawd wiary. Ten drugi postulat charakterystyczny był też m.in. dla późnośredniowiecznych radykalnych ruchów reformy życia religijnego tak w Europie Zachodniej, jak i Środkowo-Wschodniej (wiklifizm, husytyzm) - owych niespełnionych do końca prereformacji - wyrażając niezadowolenie reformatorów nie tylko z monopolu przedstawicieli hierarchicznego Kościoła na dostęp do Pisma Świętego, lecz także z małych postępów chrystianizacji wśród szerokich mas ludności.

${ }^{2}$ Cyryl i Metody - apostołowie i nauczyciele Słowian. Studia i dokumenty, red. J.S. Gajek, L. Górka, cz. 2, Lublin 1991, s. 94-96. 
Deficyty w procesie chrystianizacji miały kompensować również inne działania w ramach wczesnonowożytnych dwóch reform chrześcijaństwa, które w niemieckiej historiografii zwykło się określać mianem „konfesjonalizacji" trwającej od połowy XVI do połowy XVII w. Chodzi tutaj o zróżnicowane spektrum działań, takich jak np. dyscyplinowanie kościelne, wprowadzenie nowych rytów kościelnych oraz internalizacja zredefiniowanych konceptów teologicznych, co sprzyjało pogłębieniu chrystianizacji w szerokich kręgach społeczeństwa. Co istotne, w inicjowaniu i przeprowadzeniu konfesjonalizacji - wyraźniej w krajach protestanckich, lecz także w tych, w których pozycję dominującą utrzymał rzymski katolicyzm - istotną rolę odgrywały przede wszystkim struktury władzy państwowej, modernizujące za pomocą oficjalnie uznawanej w danym państwie konfesji całokształt życia społecznego. Rozbudowany przez historyków niemieckich model konfesjonalizacji, przeniesiony na różne kraje łacińskiej Europy, podkreśla decydujący wpływ państwa w sferze polityki kościelnej,jego dążenia monopolistyczne zmierzające do podtrzymania dominującego, uznanego za oficjalne wyznania chrześcijańskiego oraz „homogenizacji” stosunków konfesyjnych w danym kraju. Stąd też wysuwane przez część badaczy propozycje przesunięcia cezury końca „epoki konfesjonalizacji” do przełomu XVII/XVIII w. (zniesienie edyktu nantejskiego w 1685 r., ustabilizowanie dominacji anglikanizmu w latach 1688-1707, wygnanie luteranów z terenów arcybiskupstwa Salzburga w 1731 r.). Patrząc z takiej perspektywy na stosunki wyznaniowe w Rzeczypospolitej, model konfesjonalizacji dobrze nadaje się do interpretacji szeregu kluczowych w jej dziejach wydarzeń i procesów: od kościelnej unii brzeskiej, wyznaniowych aspektów powstania Chmielnickiego, wygnania arian w 1658 r., aż po wypadki związane z tumultem toruńskim $1724 \mathrm{r}$. Zdejmuje to odium wyjątkowości z rozwoju Rzeczypospolitej, w której z upływem XVII w. coraz bardziej zaznaczała się dominacja Kościoła rzymskokatolickiego i nasilały objawy braku tolerancji religijnej. Podobnego typu praktyki „konfesjonalizacyjne” będą ciągnąć się w Europie praktycznie aż do epoki oświecenia, redefiniującej rolę religii i Kościoła w państwie. To z kolei będzie stanowić jeden z najważniejszych komponentów procesu laicyzacji przestrzeni publicznej, którego geneza sięga przekształceń kulturowych zapoczątkowanych w XVIII stuleciu.

Jedną z kluczowych ról w laicyzacji europejskiej cywilizacji odegrała nowoczesna formuła tolerancji - odmienna od wspomnianej koncepcji pragmatycznego tolerowania charakterystycznej dla wczesnej epoki nowożytnej. Koncepcja kształtującego się od epoki oświecenia, upowszechniającego zaś w XIX i XX w. typu tzw. tolerancji dogmatycznej ograniczała sprawy wiary do sfery prywatnej, zakładając kompletny rozdział Kościoła od państwa, neutralność i pluralizm światopoglądowy oraz równoupraw- 
nienie wszystkich religii, a także postaw agnostycznych, czy wręcz ateistycznych, które - przynajmniej w oficjalnej wersji życia społecznego w epokach przednowoczesności były zjawiskiem zupełnie marginalnym. Określenie ,ateista” długo oznaczało w językach europejskich tyle co „bezbożnik" i było kojarzone z rozmaitego rodzaju wykroczeniami moralnymi. Dopiero od przełomu XVII/XVIII w. pojawiają się pierwsze, nie do końca zresztą jednoznaczne, próby systematyzacji poglądów antyteistycznych w Rzeczypospolitej spalonego na stosie Kazimierza Łyszczyńskiego, we Francji zaś księdza Jeana Mesliera, którego antychrześcijański „Testament” ujawniono pośmiertnie. Przyzwolenie, a potem wręcz moda pewnych środowisk na poglądy wolnomyślicielskie i wrogie chrześcijaństwu z wąskiego kręgu oświeceniowych salonów zaczęły upowszechniać się od lat czterdziestych XIX w. wskutek usystematyzowania antyteistycznego i antychrześcijańskiego światopoglądu przez Ludwika Feuerbacha, mającego znaczny wpływ m.in. na doktryny Marksa i Engelsa, lecz również prawicowe ideologie spod znaku społecznego darwinizmu. Współcześnie liczba ateistów, agnostyków lub osób deklarujących się jako niewierzące bądź religijnie obojętne - według badań przeprowadzonych w ramach projektu badania opinii publicznej Eurobarometr - w niektórych krajach w Unii Europejskiej wynosi do 85\% (Szwecja), przy czym Polska należy do nielicznych krajów, w których blisko 90\% odpowiedziało pozytywnie na pytanie, ,czy wierzę w Boga?".

W tym miejscu dotknąłem drugiego zespołu zagadnień poruszonych $\mathrm{w}$ ankiecie, a mianowicie pytań o procesy laicyzacji i dechrystianizacji. Ten ostatni termin należałoby zastrzec do planowych działań podejmowanych głównie w systemach państwowych przenikniętych przez radykalne ideologie XX w., mających na celu likwidację lub redukcję oddziaływania chrześcijańskich Kościołów oraz tradycji i sytemu wartości chrześcijaństwa. Tego typu polityka spod znaku świadomej, odgórnie przeprowadzanej „państwowej ateizacji” charakterystyczna była przede wszystkim dla Związku Sowieckiego i jego krajów satelickich lub pokrewnych ideologicznie (w Europie zwłaszcza Albania). Oczywiście prefiguracji zideologizowanej polityki „dechrystianizacyjnej” można dopatrywać się ponad stulecie wcześniej - w radykalnej fazie Wielkiej Rewolucji Francuskiej w 1793 r., w momencie deklarowanej walki z tradycjami chrześcijaństwa i promowania Religii Rozumu. Niemniej nie należy jej utożsamiać z postępującym od przełomu XVIII/XIX w. wielowątkowym procesem laicyzacji społeczeństwa, mającym o wiele szerszy zasięg i znaczenie.

Stawianie bezrefleksyjnego znaku równości między ateizacją i zeświecczeniem jest błędem, choć obecnie często występuje w sloganach ultrakonserwatywnych środowisk chrześcijańskich, przyjmujących pozycje 
defensywne wobec typowych dla współczesnej cywilizacji euroatlantyckiej postaw i wartości wynikających ze współczesnej wielokulturowości strukturalnie i substancjalnie różnej od wielokulturowości epoki wczesnonowożytnej. W przypadku współczesnej Europy jest ona spowodowana kompleksowymi procesami postkolonialnymi (migracje) oraz globalizacyjnymi - długofalową homogenizacją kultury światowej, do której paradoksalnie przyczyniła się pośrednio również ekspansja misyjna Kościołów chrześcijańskich we wcześniejszych stuleciach. Wskutek tego współczesne chrześcijaństwo - podobnie jak Stary Kontynent i jego północnoamerykański aneks - jest stopniowo pozbawiane swej uprzywilejowanej kulturowo pozycji. Kulturowo, albowiem w sferze politycznej i przestrzeni publicznej zaczęło już ją tracić wraz z procesem sekularyzacji w okresie intensywnej modernizacji w XIX i XX w.

Istotnym elementem procesów laicyzacji i modernizacji w epoce nowoczesności stała się konsekwentna polityka rozdziału Kościoła od państwa, zapoczątkowana przez reformy Józefińskie u schyłku XVIII w. W latach siedemdziesiątych XIX w. w sposób kompleksowy została przeprowadzona w nowo powstałych dużych państwach środka Europy: Królestwie Włoch i Cesarstwie Niemieckim, w tym ostatnim w opozycji do Kościoła katolickiego w ramach Kulturkampfu - który w polskiej kulturze pamięci ostał się niemal wyłącznie jako refleks Bismarckowskiej polityki germanizacji Polaków w zaborze pruskim. Z kolei w państwach nowo utworzonych po zakończeniu I wojny światowej w Europie Środkowo-Wschodniej, w tym odrodzonej Polsce, pełny rozdział Kościoła od państwa mógł zostać usankcjonowany dopiero w momencie stworzenia zrębów nowoczesnego prawodawstwa. Niewątpliwie funkcję normującą, choć także w pewnym sensie łagodzącą, miał fakt zawarcia przez Piusa XI z szeregiem tychże państw w latach dwudziestych konkordatów regulujących ich stosunki z Kościołem katolickim. Przy tym II Rzeczpospolita, podobnie jak inne utworzone po 1918 r. państwa, odziedziczyła schedę wielokulturowości po epokach wcześniejszych. Jednak międzywojenna wielokulturowość - strukturalnie różna zarówno od przednowoczesnej wielokulturowości społeczeństw stanowych, jak i postkolonialnej, zlaicyzowanej wielokulturowości po II wojnie światowej funkcjonowała już w kontekście dynamicznie modernizujących się i coraz bardziej zeświecczonych społeczeństw epoki nowoczesności.

Trudno wszakże uznać jednostronny pogląd o chrześcijaństwie (i katolicyzmie) w XIX, ale też i XX w. jako systemie pozostającym wyłącznie w opozycji do modernizacji i gwałtownych przemian epoki industrializacji. Świadczy o tym nie tylko ruch reform społecznych inicjowanych w różnych nurtach chrześcijaństwa w Europie i Stanach Zjednoczonych 
w okresie przełomów przemysłowych ${ }^{3}$, lecz także dzieje Polaków w okresie zaborów. Niektórzy przedstawiciele i środowiska polskiego Kościoła katolickiego odgrywali bowiem rolę zarówno irredentystów, jak i modernizatorów np. życia społecznego i gospodarczego. Świadczy o tym działalność szeregu ikonicznych postaci, aby wspomnieć tu księży Piotra Ściegiennego czy Piotra Wawrzyniaka. Z kolei w XX w., zarówno w okresie dwóch okupacji podczas II wojny światowej, jak i PRL nie sposób pominąć wkładu wielu przedstawicieli Kościoła katolickiego oraz jego tradycyjnych wartości w dążenia do odzyskania niepodległości oraz wspierania wielkiego ruchu społecznego protestu i żądań reform, jakim była Solidarność na przełomie lat siedemdziesiątych i osiemdziesiątych.

Wydaje się, że w chwili obecnej, gdy w głównych nurtach chrześcijaństwa, szczególnie ostro zaś w Kościele katolickim, toczą się debaty na temat tradycyjnych wartości i konfrontują głosy zwolenników Tradycji i Reformy, warto pamiętać o genezie chrześcijaństwa jako religii i systemu wartości podważających zastane tradycje i radykalnie reformującego spetryfikowany porządek. Ale odwoływanie się do początków chrześcijaństwa zawsze bywało niewygodne zarówno dla establishmentu,jak i zwolenników jego późniejszych tradycji.

${ }^{3}$ Tutaj warto zwrócić uwagę na kształtowanie się w XIX w. nowych form pobożności i życia religijnego inspirowanych właśnie procesem modernizacji. We współczesnej historiografii niemieckiej funkcjonuje nawet termin „drugie stulecie konfesjonalizacji”, określający całokształt przemian w sferze religii oraz socjotechnicznego instrumentalizowania jej przez nowoczesny aparat państwowy w tzw. długim XIX stuleciu. 